\title{
Prolonged changes in protein and amino acid metabolism after zymosan treatment in rats
}

Citation for published version (APA):

Rooyackers, O., Saris, W. H. M., Soeters, P. B., \& Wagenmakers, A. J. M. (1994). Prolonged changes in protein and amino acid metabolism after zymosan treatment in rats. Clinical Science, 87(5), 619-625. https://doi.org/10.1042/cs0870619

Document status and date:

Published: 01/01/1994

DOI:

$10.1042 / \operatorname{cs} 0870619$

Document Version:

Publisher's PDF, also known as Version of record

\section{Please check the document version of this publication:}

- A submitted manuscript is the version of the article upon submission and before peer-review. There can be important differences between the submitted version and the official published version of record.

People interested in the research are advised to contact the author for the final version of the publication, or visit the DOI to the publisher's website.

- The final author version and the galley proof are versions of the publication after peer review.

- The final published version features the final layout of the paper including the volume, issue and page numbers.

Link to publication

\footnotetext{
General rights rights.

- You may freely distribute the URL identifying the publication in the public portal. please follow below link for the End User Agreement:

www.umlib.nl/taverne-license

Take down policy

If you believe that this document breaches copyright please contact us at:

repository@maastrichtuniversity.nl

providing details and we will investigate your claim.
}

Copyright and moral rights for the publications made accessible in the public portal are retained by the authors and/or other copyright owners and it is a condition of accessing publications that users recognise and abide by the legal requirements associated with these

- Users may download and print one copy of any publication from the public portal for the purpose of private study or research.

- You may not further distribute the material or use it for any profit-making activity or commercial gain

If the publication is distributed under the terms of Article $25 \mathrm{fa}$ of the Dutch Copyright Act, indicated by the "Taverne" license above, 


\title{
Prolonged changes in protein and amino acid metabolism after zymosan treatment in rats
}

\author{
Olav E. ROOYACKERS, Wim H. M. SARIS, Peter B. SOETERS* and Anton J. M. WAGENMAKERS \\ Departments of Human Biology and *Surgery, University of Limburg, Maastricht, \\ The Netheriands
}

(Received 29 November 1993/31 May 1994; accepted 13 june 1994)

1. Intraperitoneal injections of zymosan were given to rats, according to a modified procedure, in order to create a pattern of illness with an acute critical phase for $36 \mathrm{~h}$ followed by a prolonged recovery phase lasting for at least $\mathbf{1 0}$ days. Changes in amino acid and protein metabolism were studied in both phases. 2. Differences between this modified and the original zymosan model are a lower mortality $(16 \%)$, which is limited to the first 36 critical hours, and the absence of signs of severe illness during the prolonged recovery phase.

3. Wasting of muscle protein and decreased protein synthesis rates in muscle were observed during the acute phase of illness. Liver size and liver protein synthesis rates were increased during the same period. The decrease in the total amount of muscle protein and the increase in liver weight were still present $\mathbf{1 2}$ days after zymosan treatment, despite a normalization of protein synthesis rates. Large decreases were observed in the concentrations of the conditionally essential amino acids glutamine and arginine in muscle over 6 days. Decreases in plasma glutamine and arginine on day 12 after zymosan indicated that the rats were still not fully recovered on this day.

4. We conclude that injection of a single dose of zymosan in rats leads to metabolic derangements both during the acute phase of critical illness and during the prolonged recovery phase. The model seems suited for investigating the biochemical mechanisms behind these metabolic derangements and for studying therapeutic and nutritional interventions during recovery from critical illness.

\section{INTRODUCTION}

During severe illness, such as sepsis and trauma, a complex metabolic derangement often leads to a protracted course in an intensive care unit. Loss of muscle mass and changes in the concentrations of amino acids and other metabolites are characteristic features in this period. Repeated tissue sampling for research purposes is restricted in critically ill patients for ethical reasons. Therefore, several animal models have been developed to investigate these metabolic derangements. However, the few animal models (caecal ligation and puncture, burn injury and repeated endotoxin administration) suitable for the investigation of the long-term metabolic derangements as frequently seen in man all have important limitations. With caecal ligation and puncture $[1,2]$ and burn injury $[3,4]$, invasive techniques, notably anaesthesia and surgery, are required to induce the catabolic state. Both models are also characterized by high mortality rates. Endotoxin administration results in a short-lived metabolic response, due to rapid clearance of endotoxin, unless multiple injections or constant infusions are used [5]. Prolonged or repeated administration, however, leads to endotoxin tolerance.

Goris and co-workers $[6,7]$ described a rat model for long-term illness, with clinical signs of sepsis and multiple organ failure existing for a period of 14 days. Illness in this model was induced by an aseptic intraperitoneal injection of zymosan suspended in liquid paraffin. Zymosan, which is a glucopolysaccharide from the cell wall of yeast, is a potent activator of the alternative pathway of complement [8] and of macrophages [9]. The disadvantages of this model are the high mortality rate and the large variability in severeness of disease and mortality. Here we describe a modification of the zymosan model. This modified model shows a reproducible pattern of illness starting with an acute phase of critical illness with limited mortality rates which is followed by a prolonged recovery phase without mortality and signs of severe illness. In this modified model protein synthesis rates in muscle, liver and small intestinal mucosa and concentrations of amino acids in muscle and plasma have been measured up to 12 days after zymosan treatment.

\section{METHODS}

Male Lewis rats, supplied by the central laboratory animal facilities of the University of Limburg, were individually housed and kept in a controlled environment $\left(12 \mathrm{~h}\right.$ light cycle, $21-22^{\circ} \mathrm{C}$ and $50-60 \%$ humidity). Rats were fed a standard lab chow

Key words: amino acids, critical illness, muscle wasting, protein synthesis rates, zymosan.

Abbreviations: BCAA, branched-chain amino acids; FSR, fractional protein synthesis rate; SA, specific activity.

Correspondence: Dr Olav E. Rooyackers, Department of Human Biology, University of Limburg, PO Box 616, 6200 MD Maastricht, The Netherlands. 
(SMR-A; Hope Farms, The Netherlands) containing (w/w) approximately $28 \%$ protein, $7 \%$ fat, $54 \%$ carbohydrate, $4 \%$ fibre and $7 \%$ minerals with a trace element and vitamin supplement. The rats were allowed to acclimatize for 1 week. The experiments were approved by the animal experimental committee of the University of Limburg.

Rats were given an aseptic intraperitoneal injection of zymosan $(50 \mathrm{mg} / 100 \mathrm{~g}$ body weight) suspended in liquid paraffin $(25 \mathrm{mg} / \mathrm{ml})$. The zymosan (Sigma Chemical Company) was sterilized by $\gamma$ radiation $( \pm 12000 \mathrm{rad})$. Suspensions were prepared in small portions using $25 \mathrm{ml}$ aliquots of sterilized liquid paraffin (Merck). An OMNI 1000 homogenizer (OMNI international) was used to provide a homogeneous suspension of zymosan in paraffin after which the suspension was sterilized by incubation at $100^{\circ} \mathrm{C}$ (water bath) for $90 \mathrm{~min}$.

Food intake is reduced after zymosan administration and therefore paraffin-injected control rats were pair-fed. Pair-feeding was performed in three periods during the day to ensure that the pair-fed rats would not eat all the food at once and would subsequently be starving for the remainder of the day. The three periods were from 08.00 to 15.00 hours, from 15.00 to 22.00 hours and from 22.00 to 08.00 hours.

Protein synthesis rates (muscle, liver and jejunal mucosa), tissue weight and concentrations of protein (muscle and liver) and amino acids (plasma and muscle) were measured $16 \mathrm{~h}$ and 2, 4, and 6 days after treatment with zymosan suspended in paraffin or paraffin only (pair-fed).

A control group with free access to rat chow and no paraffin injections was also included in the study. These rats were studied on day 3 to make them closely comparable with all the other experimental groups. In an additional experiment (experiment 2) tissue weights (muscle and liver) and concentrations of the amino acids glutamate, glutamine and arginine (plasma and muscle) were measured 12 days after treatment in zymosan-injected, pair-fed and ad libitum fed rats. In both experiments groups were matched for age and initial body weight. During the experiment food intake and body weight were determined daily. On the day of the experiment the rats were starved from 08.00 to 12.00 hours. Pair-feeding was performed at 07.00 hours on this day. Protein synthesis rate measurements and sampling of tissues and blood were performed between 12.00 and 14.00 hours.

To measure protein synthesis rates the phenylalanine flooding dose technique, as described by Jepson et al. [5], was used. Rats were injected intraperitoneally with a large dose of $\mathrm{L}-[4-3 \mathrm{H}]$ phenylalanine $(150 \mu \mathrm{mol}$ of phenylalanine and $20 \mu \mathrm{Ci}$ of labelled phenylalanine $/ \mathrm{ml} ; 2 \mathrm{ml} / 100 \mathrm{~g}$ body weight). After $15 \mathrm{~min}$ the rats were killed by cervical dislocation, and mixed blood was collected after decapitation. Gastrocnemius muscle, liver and jejunum were collected within $3 \mathrm{~min}$ of cervical dislocation. Muscle and liver were weighed and frozen in liquid nitrogen using a pre-cooled pair of tongs. The jejunum was transferred to ice-cold water and rinsed with ice-cold water. The mucosa was separated from the seromuscular layer by scraping with a ice-cold glass slide and was frozen in liquid nitrogen using a pre-cooled pair of tongs.

For measurement of the incorporation of $\left[{ }^{3} \mathrm{H}\right]$ phenylalanine into tissue protein the method described by Garlick et al. [10] was used. The same samples were used to measure protein concentration using the method of Lowry et al. [11]. Fractional protein synthesis rate (FSR) was calculated from the specific activity (SA; d.p.m./nmol) of $\left[{ }^{3} \mathrm{H}\right]$ phenylalanine in the precursor pool (intracellular phenylalanine) and the SA of protein-bound $\left[{ }^{3} \mathrm{H}\right]$ phenylalanine. To calculate the FSR in muscle the SA of intracellular phenylalanine was multiplied by 0.9 as described by Jepson et al. [5] because plateau labelling of the precursor pool in muscle is reached after 2 or $3 \mathrm{~min}$ only. For liver this correction factor was 1.0 [5]. It was assumed that the correction factor for small intestine also is 1.0 .

$$
\mathrm{FSR}=\frac{\mathrm{SA}_{\text {protein-bound }}}{\mathrm{SA}_{\text {precursor }} \times \text { time }(\text { days })} \times 100 \%
$$

In a pilot experiment it was shown that no difference existed between zymosan-treated and control rats in the time to reach plateau labelling $(1-2 \mathrm{~min})$ and in the maintenance of the plateau for at least $20 \mathrm{~min}$ in blood after a flooding dose of $\left[{ }^{3} \mathrm{H}\right]$ phenylalanine.

Free amino acids in muscle and plasma were measured by h.p.l.c. [12]. Plasma was deproteinized with sulphosalicylic acid. Intracellular amino acids in muscle were extracted using a 5\% sulphosalicylic acid solution with norvaline $(0.5 \mathrm{mmol} / \mathrm{l})$ as an internal standard. Concentrations of glutamate, glutamine and arginine in muscle and plasma from experiment 2 were measured using enzymic assays as described previously $[13,14]$.

All measurements were performed in duplicate, except for muscle protein synthesis rates, which were performed in triplicate. Values are given as mean (range). The Mann-Whitney $U$-test was used to determine statistically significant differences between the zymosan-treated and pair-fed rats at one time point and between the zymosan-treated and the ad libitum fed control rats. Significance was set at $P<0.05$.

\section{RESULTS}

\section{The rat model}

All rats injected with zymosan showed signs of severe illness, including lethargy, anorexia, diarrhoea and loss of haemorrhagic fluid from nose and eyes for 2 days after zymosan administration. The peritoneal cavity yielded remnants of paraffin, and adhesions between abdominal organs were found 2, 4, 6 


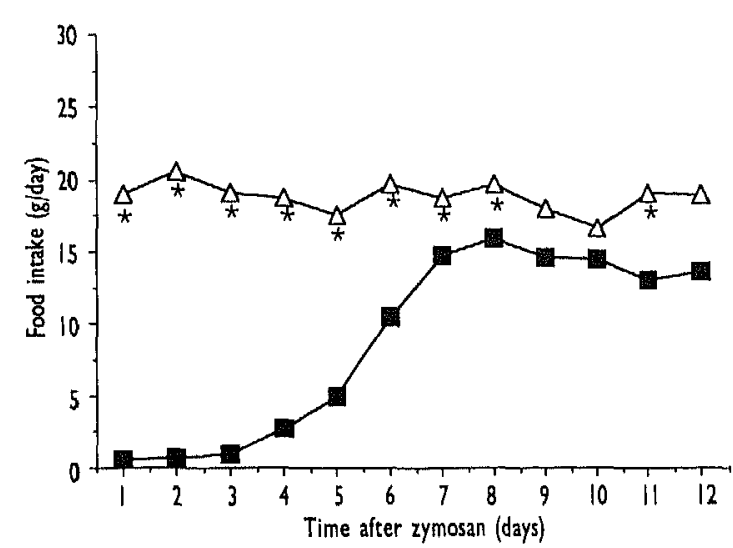

Fig. I. Food intake of control $(\triangle)$ and zymosan-treated (D) rats. Values from experiment 2 are given, in which rats were studied for 12 days after zymosan treatment. The rats in experiment 1 followed the same pattern of food intake for the 6 days that they were studied. Statistical significance: ${ }^{*}<0.05$ compared with control rats.

and 12 days after zymosan treatment. The liver was pale and had adhesions with the diaphragm and stomach. The pair-fed rats (injected with paraffin only) and the ad libitum fed rats showed none of these abnormalities. Sixteen per cent of the zymosan-treated animals died during the first $36 \mathrm{~h}$ after injection. No animals died hereafter, Due to the induction of the illness food intake was dramatically reduced. Intake was reduced to $0.5 \mathrm{~g} / \mathrm{day}$ on days 1 and 2, after which it slowly increased to $70-$ $80 \%$ of the normal intake between days 7 and 12 after zymosan treatment (Fig. 1).

The initial body weights were not significantly different between the experimental groups in both experiments (Tables 1 and 2). The rats from experiment 2 , however, had higher initial body weights in comparison with those of experiment 1 . Due to the treatment both the pair-fed and the zymosan-treated rats lost weight in comparison with the fed control rats (Fig. 2). A decrease in weight was seen during the first 4 days, followed by a small increase. No catch-up growth was observed. The reduction in body weight in the pair-fed group was larger than in the zymosan-treated rats. Muscle (gastrocnemius) weight (expressed per $100 \mathrm{~g}$ of initial body weight) was reduced in the zymosan-treated rats in comparison with the ad libitum fed control rats $16 \mathrm{~h}$ after treatment and with both the ad libitum fed and pairfed rats on day 2, 4,6 and 12 (Table 1 and 2). Due to the zymosan treatment liver weight (expressed per $100 \mathrm{~g}$ of initial body weight) was increased in comparison with the pair-fed rats during the whole experiment ( $16 \mathrm{~h}$ and $2,4,6$, and 12 days), decreased in comparison with the fed control rats on $16 \mathrm{~h}$ and day 2 , but greater than the fed control rats on day 12 (Tables 2 and 3 ).

\section{Protein metabolism}

No differences in muscle protein concentration and wet/dry weight ratio were observed in the zymosan-treated rats in comparison with the ad libitum fed and pair-fed control rats (Table 1). Total muscle protein content (expressed per $100 \mathrm{~g}$ of initial body weight) was decreased in the zymosan-treated rats $2,4,6$ and 12 days after treatment in comparison with the ad libitum fed and pair-fed control rats (Tables 1 and 2). Total liver protein content (expressed per $100 \mathrm{~g}$ of initial body weight) was significantly decreased in the zymosan-treated group in comparison with the ad libitum fed control rats $16 \mathrm{~h}$ and 2 and 4 days after treatment, but was increased compared with the pair-fed group on days 2, 4 and 6 (Table 3).

FSR in muscle was decreased in the zymosantreated rats in comparison with the pair-fed and fed control rats $16 \mathrm{~h}$ after treatment (Table 4 ). On days 2 and 4 after treatment FSR was decreased in muscle of the zymosan-treated rats in comparison with the fed control rats. No difference, however, was seen at these time points between the zymosantreated and pair-fed rats. FSR in liver in the zymosan-treated rats was increased $16 \mathrm{~h}, 2$ days and 4 days after treatment in comparison with the pairfed rats (Table 4). In comparison with the fed control rats an increase was seen 2 days after treatment. FSR in the mucosal layer of the jejunum was decreased in the zymosan-treated rats on day 6 in comparison with both control groups (Table 4).

\section{Amino acid metabolism}

Both in plasma (Table 5) and muscle (Table 6) the sum of the amino acid concentrations was decreased 2, 4 and 6 days after zymosan treatment in comparison with one or both of the control groups. The concentrations of phenylalanine and tyrosine are not included because these are higher than the physiological values due to the flooding dose of phenylalanine given for measuring FSR. Most essential amino acids (threonine, methionine, tryptophan, lysine, valine, leucine, isoleucine) were decreased in concentration in plasma 2,4 and 6 days after treatment (Table 5). Of the non-essential amino acids, plasma concentrations of glutamate and glutamine were decreased on days 6 and 12 and of arginine on days 4,6 and 12 after zymosan treatment (Tables 5 and 7). In muscle, of the essential amino acids, threonine was decreased days 2, 4 and 6 after treatment, lysine on days 2 and 4 , and the sum of the branched-chain amino acids (BCAA; valine, leucine and isoleucine) on days 4 and 6 (Table 6). Of the non-essential amino acids, both the concentrations of glutamine and arginine were decreased on days 2,4 and 6 . No differences in concentrations of glutamate, glutamine and arginine were observed in muscle 12 days after treatment (Table 7).

\section{DISCUSSION}

Many animal models have been developed to study the metabolic response to trauma and sepsis 
Table I. Initial body weight and gastrocnemius weight, protein content, total protein, and dry/wet weight ratio $16 \mathrm{~h}$ and 2, 4 and 6 days after treatment. Values are given as mean (range) for six to eight rats. Abbreviations: CON, od libitum fed control rats; ZYM, zymosan-injected rats; PF, pair-fed rats; NA, not analysed, *Significantly different from control rats; †significantly different from pair-fed rats.

\begin{tabular}{|c|c|c|c|c|c|}
\hline & $\begin{array}{l}\text { Initial body } \\
\text { wt. (g) }\end{array}$ & $\begin{array}{l}\text { Muscle wt. } \\
\text { (g/100 g initial } \\
\text { body wt.) }\end{array}$ & $\begin{array}{l}\text { Protein (mg/g } \\
\text { wet wt.) }\end{array}$ & $\begin{array}{l}\text { Total protein } \\
\text { (mg } / 00 \mathrm{~g} \text { initial } \\
\text { body wt.) }\end{array}$ & $\begin{array}{l}\text { Dry/wet } \\
\text { wt. ratio }\end{array}$ \\
\hline CON & $178(146-223)$ & $0.74(0.67-0.98) \ddagger$ & $180.8(163.5-196.0)$ & $133.3(\mid 19.7-161.0) \ddagger$ & $0.24(0.22-0.27)$ \\
\hline \multicolumn{6}{|l|}{$16 \mathrm{~h}$} \\
\hline ZYM & $207(195-229)$ & $0.55(0.52-0.59)^{*}$ & NA & NA & NA \\
\hline $\mathrm{PF}$ & $2 \mid 1(202-230)$ & $0.56(0.45-0.60)$ & NA & NA & NA \\
\hline \multicolumn{6}{|l|}{2 days } \\
\hline$Z Y M$ & $184(157-236)$ & $0.45(0.42-0.49)^{*} \dagger$ & $162.2(\mid 24.7-186.7)$ & $73.6(58.2-90.2)^{*} \uparrow$ & $0.24(0.21-0.27)$ \\
\hline $\mathrm{PF}$ & $191(172-243)$ & $0.54(0.51-0.55)$ & $175.1(144.0-187.1)$ & $94.8(79.0-102.0)$ & $0.24(0.23-0.25)$ \\
\hline \multicolumn{6}{|l|}{4 days } \\
\hline$Z Y M$ & $180(156-228)$ & $0.39(0.24-0.44)^{*} \dagger$ & $165.8(157.7-184.2)$ & $69.7(61.5-75.9)^{*} \dagger$ & $0.25(0.22-0.29)$ \\
\hline $\mathrm{PF}$ & $197(169-236)$ & $0.50(0.44-0.56)$ & $169.3(152.5-184.2)$ & $84.9(76.5-93.9)$ & $0.24(0.23-0.24)$ \\
\hline \multicolumn{6}{|l|}{6 days } \\
\hline ZYM & $184(147-225)$ & $0.44(0.41-0.50)^{*}+$ & $172.7(166.2-179.9)$ & $74.8(68.1-85.5)^{*} \dagger$ & $0.24(0.23-0.26)$ \\
\hline PF & $188(15 \mid-227)$ & $0.54(0.51-0.57)$ & $176.7(158.7-184.3)$ & $95.9(86.6-104.3\rangle$ & $0.24(0.22-0.24)$ \\
\hline
\end{tabular}

IValues of the od libitum fed rats were obtained on day 3 to make them comparable with all other groups. Because growing rats are used these numbers should be slightly smaller for the younger rats and larger for the older rats.

\begin{tabular}{|c|c|c|c|c|c|}
\hline & \multirow[b]{2}{*}{$\begin{array}{l}\text { Initial body } \\
\text { Wt. (g) }\end{array}$} & \multicolumn{3}{|c|}{ Muscle } & \multirow[b]{2}{*}{$\begin{array}{l}\text { Liver wt. } \\
\text { (g } 1100 \mathrm{~g} \text { Initial } \\
\text { body wt.) }\end{array}$} \\
\hline & & $\begin{array}{l}\text { Wt. } \\
\text { (g/100g initial } \\
\text { body wt.) }\end{array}$ & $\begin{array}{l}\text { Protein (mg/g } \\
\text { wet wt.) }\end{array}$ & $\begin{array}{l}\text { Total protein } \\
\text { (mg/loog initial } \\
\text { body wt.) }\end{array}$ & \\
\hline $\mathrm{CON}$ & $264(239-295)$ & $0.65(0.62-0.66)$ & $216.7(182.7-263.4)$ & $141.2(113.6-174.0)$ & $4.0(3.5-4.6)$ \\
\hline ZYM & $269(258-277)$ & $0.41(0.35-0.46)^{* \dagger}$ & $207.9(\mid 82.2-226.1)$ & $86.3(67.7-100.7)^{*}+$ & $4.8(4,4-5.1)^{*} \dagger$ \\
\hline PF & $269(256-275)$ & $0.54(0.46-0.61)$ & $225.1(188.6-296.9)$ & $122.8(92.5-170.4)$ & $3.1(2,8-3.5)$ \\
\hline
\end{tabular}

(for a review, see [15]). However, most models only show an acute severe and short-lived period of illness. A simple intraperitoneal injection with zymosan suspended in paraffin, as used here, provided a model for studying both an acute phase of critical illness and a prolonged recovery phase.

Zymosan treatment has been used in several studies as a model for critical illness and multiple organ failure. Goris and co-workers $[6,7]$, who introduced the model in rats, described a triphasic illness. On the first 3 days clinical signs of critical illness were observed, such as lethargy, anorexia, hyperventilation, diarrhoea and loss of haemorrhagic fluid from nose and eyes. A stable intermediate period was then followed by the development of a second phase of severe illness, with signs of multiple organ failure between 7 and 14 days after zymosan treatment. Steinberg et al. [9] described histopathological changes in lung, liver and kidney 7 days after zymosan administration, from which they concluded that the injection of zymosan in rats created a model for multiple organ failure.

Several pilot experiments performed in our labor- atory showed that the model as described by Goris and co-workers $[6,7]$ led to varying degrees of illness and variable mortality rates in repeated experiments. Much effort, therefore, has been put into improvement of the reproducibility of the model. The procedure to prepare the zymosan suspension has been modified (see the Methods section) and the dose of zymosan was reduced to half the dose administered by Goris and co-workers $[6,7]$. This resulted in a decrease in acute mortality to $16 \%(35 \%$ in the studies of Goris and co-workers [6, 7]), whereafter no additional rats died (another 15\% in the studies of Goris and co-workers $[6,7])$. This modified model has led to a reproducible pattern of illness in six different experiments performed in our laboratory over the last 2 years with a total of 132 rats. Rats showed signs of severe illness over 2-3 days, after which they slowly recovered, as indicated by increasing food intake and gain in body weight. During the phase of severe illness characteristic changes in protein metabolism with muscle protein wasting, decreased muscle protein synthesis rates, increased liver weight and enhanced liver protein 


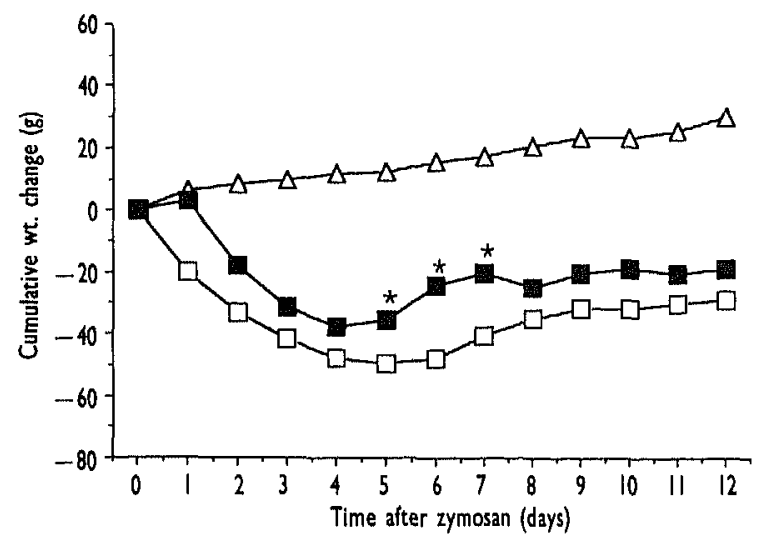

Fig. 2. Cumulative changes in body weight of control $(\Delta)$, pair-fed $(\square)$ and zymosan-treated (D) rats. Values from experiment 2 are given, in which rats were studied for 12 days after zymosan treatment. The rats in experiment 1 followed the same pattern of cumulative weight change for the 6 days that they were studied. Rats were injected with either zymosan suspended in paraffin or with paraffin only (pair-fed). Control rats were not injected. Changes were calculated from initial body weight and body weights attained every morning during the experiment. Sixteen hour values were measured just before the rats were killed. All values for the zymosan-treated and the pair-fed rats are significantly different from those of the control rats, except on day 0 and 1 for the pair-fed rats, Statistical significance: $* p<0.5$ between zymosan-treated and pair-fed rats.

Table 3. Liver weight, protein and total protein $16 \mathrm{~h}$ and 2,4 and 6 days after treatment. Values are given as mean (range) for six to eight rats. Abbreviations: CON, od libitum fed control rats; ZYM, zymosaninjected rats; $P F$, pair-fed rats. *SIgnificantly different from control rats; tsignificantly different from pair-fed rats.

\begin{tabular}{|c|c|c|c|}
\hline & $\begin{array}{l}\text { Liver wt. } \\
\text { (g/l00g initia\} } \\
\text { body wt.) }\end{array}$ & $\begin{array}{l}\text { Protein } \\
(m g / g \text { wet wt.) }\end{array}$ & $\begin{array}{l}\text { Total protein } \\
\text { (mg/loog initial } \\
\text { body wt.) }\end{array}$ \\
\hline CON & $5.2(4.2-6.0) \ddagger$ & $194.8(186.3-208.7)$ & $1008(830-1135) \ddagger$ \\
\hline \multicolumn{4}{|l|}{$16 \mathrm{~h}$} \\
\hline ZYM & $3.7(3.4-3.9)^{*} \dagger$ & $202.4(187.7-218.0) \dagger$ & $744(642-828)^{*}$ \\
\hline $\mathrm{PF}$ & $3.1(3.0-3.2)$ & $224.9(215.3-231.3)$ & $700(666-729)$ \\
\hline \multicolumn{4}{|l|}{2 days } \\
\hline ZYM & $3.9(3.8-4.3)^{*} \dagger$ & $187.3(174.7-196.4) \dagger$ & $738(679-778)^{*} \dagger$ \\
\hline PF & $2.9(2.4-3.2)$ & $205.3(182.0-218.3)$ & $589(517-636)$ \\
\hline \multicolumn{4}{|l|}{4 days } \\
\hline ZYM & $4.8(4.6-5.2) \dagger$ & $168.5(125.4-189.5)^{*}$ & $811(606-949)^{*}+$ \\
\hline$P F$ & $3.3(2.8-3.6)$ & $180.6(166.5-195.9)$ & $592(504-650)$ \\
\hline \multicolumn{4}{|l|}{6 days } \\
\hline ZYM & $5.1(4.6-5.8) \dagger$ & $176.9(132.7-199.3)$ & $895(718-998) \dagger$ \\
\hline PF & $4.0(3.2-4.4)$ & $173.5(165.4-186.8)$ & $687(552-757)$ \\
\hline
\end{tabular}

\$Values of the ad libitum fed rats were obtained on day 3 to make them comparable with all other groups. Because growing rats are used these numbers should be slightly smaller for the younger rats and larger for the older rats.

synthesis rates were observed. Although the rats did not show signs of critical illness between days 6 and 12 , changes in food intake, body weight, tissue weight and protein (days 6 and 12), concentrations of glutamine and arginine in plasma (days 6 and 12) and muscle (day 6) and mucosal protein synthesis rates (day 6) indicate that the zymosan-treated rats
Table 4. FSR in gastrocnemius, liver and mucosal layer of the jejunum $16 \mathrm{~h}$ and 2,4 and 6 days after treatment. Values are given as mean (range) for six to eight rats. Abbreviations: CON, ad libitum fed control rats; ZYM, zymosan-injected rats; PF, pair-fed rats, *Significantly different from control rats; †significantly different from pair-fed rats.

\begin{tabular}{llll}
\hline & \multicolumn{3}{c}{ FSR (\%/day) } \\
\cline { 2 - 4 } CON & Muscle & Liver & Mucosa \\
\hline I6h & $8.2(6.8-9.8)$ & $78.7(66.7-102.6)$ & $83.1(67.9-91.6)$ \\
ZYM & $5.3(4.3-6.5)^{* \dagger}$ & $74.1(60.1-87.7) \dagger$ & $105.2(67.2-142.7)$ \\
PF & $9.5(7.5-10.5)$ & $53.4(46.3-58.4)$ & $92.5(38.7-145.4)$ \\
2 days & & & \\
ZYM & $5.1(3.4-6.8)^{*}$ & $113.5(78.8-143.9)^{*} \dagger$ & $74.2(60.6-87.8)$ \\
PF & $5.7(3.7-8.0)$ & $77.4(59.6-99.5)$ & $78.4(67.9-87.1)$ \\
4 days & & & \\
ZYM & $5.8(4.2-9.2)^{*}$ & $88.6(73.7-100.4) \dagger$ & $72.9(61.9-88.4)$ \\
PF & $5.7(3.8-7.2)$ & $72.9(58.8-85.2)$ & $78.2(59.8-99.9)$ \\
6 days & & & \\
ZYM & $6.9(5.6-8.1)$ & $81.9(67.2-99.1)$ & $66.1(52.4-77.0)^{* \dagger}$ \\
PF & $6.5(3.9-8.1)$ & $70.0(55.8-88.9)$ & $85.5(59.3-98.4)$ \\
\hline
\end{tabular}

were not fully recovered. There were, however, no signs of severe illness or multiple organ failure during this period in the modified model.

Muscle mass was found to be decreased on days 2, 4, 6 and 12 after zymosan treatment, and, since both the dry/wet weight ratio and the protein concentrations in the gastrocnemius muscle at these time points were unchanged, this suggests that the net loss was due to a reduction in muscle tissue. Both the pair-fed and the zymosan-treated rats lost muscle tissue; however, in the pair-fed rats this was in proportion to the decreased body weight due to the semi-starvation. The larger loss in the zymosaninjected rats indicates that the wasting of muscle is the result of net protein catabolism induced by severe illness. If this protein wasting applies to the whole skeletal muscle compartment of the rat then the smaller loss of body weight in the zymosantreated rats in comparison with the pair-fed rats may be the result of increased water retention in the zymosan-treated rats. In critically ill patients water is often sequestered as non-functional extracellular fluid [16].

Muscle wasting is a common feature during severe illness in humans and is often, at least in part, the result of decreased protein synthesis rates [17]. In most animal models of sepsis and critical illness wasting of muscle mass is accompanied by reduced protein synthesis rates $[5,18,19]$. In the zymosan-injected rats muscle protein synthesis rates were reduced $16 \mathrm{~h}$ after treatment in comparison with the pair-fed animals. Also, altered protein breakdown rates may contribute to the changes in protein content, but these were not measured because no reliable method for measurements in vivo is available in rats. The difference in total muscle protein content between zymosan-injected and pairfed rats did not increase further after day 2 . 


\begin{tabular}{|c|c|c|c|c|c|c|c|}
\hline \multirow{3}{*}{$\begin{array}{l}\text { Amino } \\
\text { acid }\end{array}$} & \multicolumn{7}{|c|}{ Concn. $(\mu$ mol/ll) } \\
\hline & \multicolumn{2}{|c|}{2 days } & \multicolumn{2}{|c|}{4 days } & \multicolumn{2}{|c|}{6 days } & \multirow[t]{2}{*}{ Control } \\
\hline & Zymosan-injected & Pair-fed & Zymosan-injected & Pair-fed & Zymosan-injected & Pair-fed & \\
\hline Glu & $\begin{array}{l}103 \\
(58-166)\end{array}$ & $\begin{array}{l}113 \\
(60-170)\end{array}$ & $\begin{array}{l}94 \\
(70-125)\end{array}$ & $\begin{array}{l}82 \\
(73-93)\end{array}$ & $\begin{array}{l}70^{*} \dagger \\
(60-79)\end{array}$ & $\begin{array}{l}90 \\
(68-115)\end{array}$ & $\begin{array}{l}124 \\
(81-198)\end{array}$ \\
\hline Asn & $\begin{array}{l}58 * \\
(48-75)\end{array}$ & $\begin{array}{l}64 \\
(50-78)\end{array}$ & $\begin{array}{l}33 \uparrow \\
(22-41)\end{array}$ & $\begin{array}{l}47 \\
(41-59)\end{array}$ & $\begin{array}{l}31^{*} \\
(24-33)\end{array}$ & $\begin{array}{l}40 \\
(23-62)\end{array}$ & $\begin{array}{l}40 \\
(30-50)\end{array}$ \\
\hline Ser & $\begin{array}{l}255 \dagger \\
(201-395)\end{array}$ & $\begin{array}{l}316 \\
(246-418)\end{array}$ & $\begin{array}{l}192^{*} \dagger \\
(152-267\rangle\end{array}$ & $\begin{array}{l}352 \\
(316-434)\end{array}$ & $\begin{array}{l}221 \dagger \\
(140-376)\end{array}$ & $\begin{array}{l}381 \\
(327-422)\end{array}$ & $\begin{array}{l}262 \\
(210-302)\end{array}$ \\
\hline Gln & $\begin{array}{l}635 \\
(542-740)\end{array}$ & $\begin{array}{l}754 \\
(524-917)\end{array}$ & $\begin{array}{l}664 \\
(625-705)\end{array}$ & $\begin{array}{l}648 \\
(564-762)\end{array}$ & $\begin{array}{l}552 \dagger \\
(361-670)\end{array}$ & $\begin{array}{l}740 \\
(600-894)\end{array}$ & $\begin{array}{l}637 \\
(500-683)\end{array}$ \\
\hline Gly & $\begin{array}{l}342 \\
(194-594)\end{array}$ & $\begin{array}{l}361 \\
(256-439)\end{array}$ & $\begin{array}{l}308 * \dagger \\
(279-373)\end{array}$ & $\begin{array}{l}492 \\
(439-604)\end{array}$ & $\begin{array}{l}238 * \dagger \\
(214-257)\end{array}$ & $\begin{array}{l}477 \\
(376-577)\end{array}$ & $\begin{array}{l}395 \\
(333-483)\end{array}$ \\
\hline Thr & $\begin{array}{l}177 \dagger \\
(125-308)\end{array}$ & $\begin{array}{l}266 \\
(184-320)\end{array}$ & $\begin{array}{l}100^{*} \dagger \\
(85-119)\end{array}$ & $\begin{array}{l}263 \\
(229-310)\end{array}$ & $\begin{array}{l}174 \dagger \\
(122-253)\end{array}$ & $\begin{array}{l}230 \\
(194-265)\end{array}$ & $\begin{array}{l}208 \\
(155-232)\end{array}$ \\
\hline His & $\begin{array}{l}73 \\
(45-97)\end{array}$ & $\begin{array}{l}63 \\
(46-88)\end{array}$ & $\begin{array}{l}60 \\
(55-66)\end{array}$ & $\begin{array}{l}67 \\
(59-79)\end{array}$ & $\begin{array}{l}52 \uparrow \\
(40-57)\end{array}$ & $\begin{array}{l}65 \\
(5 \mid-76)\end{array}$ & $\begin{array}{l}60 \\
(47-73)\end{array}$ \\
\hline Cit & $\begin{array}{l}72 \\
(49-105)\end{array}$ & $\begin{array}{l}81 \\
(59-102)\end{array}$ & $\begin{array}{l}75 \\
(57-84)\end{array}$ & $\begin{array}{l}78 \\
(65-94)\end{array}$ & $\begin{array}{l}90 \\
(73-126)\end{array}$ & $\begin{array}{l}98 \\
(74-134)\end{array}$ & $\begin{array}{l}82 \\
(60-106)\end{array}$ \\
\hline Ala & $\begin{array}{l}344 \\
(227-603)\end{array}$ & $\begin{array}{l}307 \\
(237-427)\end{array}$ & $\begin{array}{l}276 \\
(224-314)\end{array}$ & $\begin{array}{l}359 \\
(283-510)\end{array}$ & $\begin{array}{l}208 \\
(182-242)\end{array}$ & $\begin{array}{l}347 \\
(290-397)\end{array}$ & $\begin{array}{l}242 \\
(197-270)\end{array}$ \\
\hline Tau & $\begin{array}{l}126^{*} \\
(65-253)\end{array}$ & $\begin{array}{l}156 \\
(124-182)\end{array}$ & $\begin{array}{l}147 \\
(80-285)\end{array}$ & $\begin{array}{l}223 \\
(136-392)\end{array}$ & $\begin{array}{l}108 * \uparrow \\
(79-162)\end{array}$ & $\begin{array}{l}288 \\
(224-376)\end{array}$ & $\begin{array}{l}210 \\
(136-274)\end{array}$ \\
\hline $\operatorname{Arg}$ & $\begin{array}{l}133 \\
(85-2 \mid 0)\end{array}$ & $\begin{array}{l}160 \\
(116-207)\end{array}$ & $\begin{array}{l}81 *+ \\
(73-89)\end{array}$ & $\begin{array}{l}171 \\
(136-212)\end{array}$ & $\begin{array}{l}74^{*} \dagger \\
(55-107)\end{array}$ & $\begin{array}{l}152 \\
(100-200)\end{array}$ & $\begin{array}{l}146 \\
(112-185)\end{array}$ \\
\hline Met & $\begin{array}{l}44 \\
(35-52)\end{array}$ & $\begin{array}{l}46 \\
(36-59)\end{array}$ & $\begin{array}{l}27^{*}+ \\
(23-30)\end{array}$ & $\begin{array}{l}45 \\
(38-56)\end{array}$ & $\begin{array}{l}21^{*} \dagger \\
(18-25)\end{array}$ & $\begin{array}{l}38 \\
(28-48)\end{array}$ & $\begin{array}{l}39 \\
(30-47)\end{array}$ \\
\hline Trp & $\begin{array}{l}56 \dagger \\
(44-77)\end{array}$ & $\begin{array}{l}69 \\
(51-89)\end{array}$ & $\begin{array}{l}34^{*} \dagger \\
(26-45)\end{array}$ & $\begin{array}{l}80 \\
(62-101)\end{array}$ & $\begin{array}{l}42 * \uparrow \\
(32-56)\end{array}$ & $\begin{array}{l}61 \\
(43-73)\end{array}$ & $\begin{array}{l}59 \\
(42-69)\end{array}$ \\
\hline Lys & $\begin{array}{l}329+ \\
(274-427)\end{array}$ & $\begin{array}{l}421 \\
(323-517)\end{array}$ & $\begin{array}{l}269 * \\
(176-352)\end{array}$ & $\begin{array}{l}326 \\
(203-415)\end{array}$ & $\begin{array}{l}347 \\
(330-559)\end{array}$ & $\begin{array}{l}342 \\
(246-476)\end{array}$ & $\begin{array}{l}372 \\
(324-423)\end{array}$ \\
\hline Val & $\begin{array}{l}175 \\
(\mid 30-232)\end{array}$ & $\begin{array}{l}183 \\
(117-222)\end{array}$ & $\begin{array}{l}104^{*} \dagger \\
(91-110)\end{array}$ & $\begin{array}{l}163 \\
(126-192)\end{array}$ & $\begin{array}{l}114^{* \dagger} \\
(98-139)\end{array}$ & $\begin{array}{l}183 \\
(137-219)\end{array}$ & $\begin{array}{l}158 \\
(112-188\rangle\end{array}$ \\
\hline He & $\begin{array}{l}71 \\
(56-91)\end{array}$ & $\begin{array}{l}81 \\
(51-108)\end{array}$ & $\begin{array}{l}44^{*} \\
(40-48)\end{array}$ & $\begin{array}{l}52 \\
(39-63)\end{array}$ & $\begin{array}{l}41 * \dagger \\
(36-46)\end{array}$ & $\begin{array}{l}63 \\
(49-75)\end{array}$ & $\begin{array}{l}63 \\
(49-72)\end{array}$ \\
\hline Leu & $\begin{array}{l}124 \\
(97-167)\end{array}$ & $\begin{array}{l}127 \\
(82-172)\end{array}$ & $\begin{array}{l}70^{*+\phi} \\
(61-77)\end{array}$ & $\begin{array}{l}98 \\
(67-122)\end{array}$ & $\begin{array}{l}69 * \dagger \\
(59-83)\end{array}$ & $\begin{array}{l}104 \\
(84-124)\end{array}$ & $\begin{array}{l}102 \\
(75-|2|)\end{array}$ \\
\hline BCAA & $\begin{array}{l}369 \\
(283-482)\end{array}$ & $\begin{array}{l}390 \\
(250-495)\end{array}$ & $\begin{array}{l}219 * \dagger \\
(193-234)\end{array}$ & $\begin{array}{l}313 \\
(232-374)\end{array}$ & $\begin{array}{l}225 * \dagger \\
(193-268)\end{array}$ & $\begin{array}{l}351 \\
(270-410)\end{array}$ & $\begin{array}{l}323 \\
(236-381)\end{array}$ \\
\hline Sum & $\begin{array}{l}2932 \dagger \\
(2674-3387)\end{array}$ & $\begin{array}{l}3567 \\
(2898-4167)\end{array}$ & $\begin{array}{l}2580 * \dagger \\
(2381-2829)\end{array}$ & $\begin{array}{l}3525 \\
(2983-4431)\end{array}$ & $\begin{array}{l}2471^{*} \dagger \\
(2175-2680)\end{array}$ & $\begin{array}{l}3697 \\
(300|-4| 89)\end{array}$ & $\begin{array}{l}3194 \\
(2508-3660)\end{array}$ \\
\hline
\end{tabular}

In contrast to muscle, liver protein synthesis rates were increased not only in the critical phase but also on day 4. Increases in total liver protein content and liver protein synthesis rates have also been observed in rats treated with endotoxin and turpentine $[5,18]$. This response may, in part, be a reflection of the increased synthesis rate of (retained) acute phase and endogenous proteins in liver.

Decreased concentrations of BCAA in plasma and muscle were seen 4 and 6 days after zymosan treatment in comparison with pair-fed and fed controls. During severe illness a reduction in plasma BCAA concentration has been observed $[20,21]$. In the study by Stinnett et al. [22] decreased plasma and intracellular muscle concentrations of $\mathrm{BCAA}$ were seen in both patients and animals with severe burn injury. Enhanced whole body and muscle oxidation rates of $\mathrm{BCAA}$, reported during sepsis, burn injury and trauma $[23,24]$, may be the cause of these reduced concentrations.

Concentrations of the non-essential amino acid glutamine in muscle were reduced in comparison with the pair-fed and fed control rats until 6 days after zymosan treatment. Plasma concentrations of glutamine were maintained until 6 days after zymosan treatment and were reduced on day 12 after treatment. Decreased concentrations of glutamine in muscle have been repeatedly reported in critically ill patients $[25,26]$ and in animal models $[1,3,18]$. Glutamine levels in human muscle stay low during a prolonged period (30 days) in contrast to changes in concentrations of other amino acids [27]. Glutamine has more metabolic functions than any other amino acid [28] and is, therefore, suggested to become essential during severe illness [29].

A positive correlation has been reported between 
Table 6. Gastrocnemius concentrations of amino acids 2, 4 and 6 days after treatment. Vaiues are given as mean (range) for six to eight rats. *Significantly different from control; †significantly different from pair-fed rats.

\begin{tabular}{|c|c|c|c|c|c|c|c|}
\hline \multirow{3}{*}{$\begin{array}{l}\text { Amino } \\
\text { acid }\end{array}$} & \multicolumn{6}{|c|}{ Conen. (nmol/g wet wt.) } & \multirow{3}{*}{ Control } \\
\hline & \multicolumn{2}{|c|}{2 days } & \multicolumn{2}{|c|}{4 daył } & \multicolumn{2}{|c|}{6 days } & \\
\hline & Zymosan-injected & Pair-fed & Zymosan-injected & Pair-fed & Zymosan-injected & Pair-fed & \\
\hline Glu & $\begin{array}{l}1432 \\
\langle 775-2| 33)\end{array}$ & $\begin{array}{l}1470 \\
(1425-1532)\end{array}$ & $\begin{array}{l}1326 \\
(1061-1520)\end{array}$ & $\begin{array}{l}1146 \\
(629-2279)\end{array}$ & $\begin{array}{l}1442 \\
(400-2221)\end{array}$ & $\begin{array}{l}1332 \\
(1155-\mid 596)\end{array}$ & $\begin{array}{l}1646 \\
(979-2471)\end{array}$ \\
\hline Asn & $\begin{array}{l}118^{*} \dagger \\
(62-163\rangle\end{array}$ & $\begin{array}{l}160 \\
(138-187)\end{array}$ & $\begin{array}{l}98 \\
(61-149)\end{array}$ & $\begin{array}{l}15 ! \\
(57-340)\end{array}$ & $\begin{array}{l}74 \\
(48-91)\end{array}$ & $\begin{array}{l}92 \\
(6|-| 20)\end{array}$ & $\begin{array}{l}8 \mid \\
(67-97)\end{array}$ \\
\hline Ser & $\begin{array}{l}387 * \dagger \\
(297-537)\end{array}$ & $\begin{array}{l}691 \\
(555-880)\end{array}$ & $\begin{array}{l}467^{*} \dagger \\
(377-598)\end{array}$ & $\begin{array}{l}1033 \\
(489-2028)\end{array}$ & $\begin{array}{l}506 \dagger \\
(310-834)\end{array}$ & $\begin{array}{l}866 \\
(747-1015)\end{array}$ & $\begin{array}{l}711 \\
(372-1001)\end{array}$ \\
\hline Gln & $\begin{array}{l}1042^{*} \dagger \\
(627-1374)\end{array}$ & $\begin{array}{l}2151 \\
(1717-2534)\end{array}$ & $\begin{array}{l}1957 \\
(1515-3072)\end{array}$ & $\begin{array}{l}2522 \\
(\mid 123-5291)\end{array}$ & $\begin{array}{l}1637^{*} \dagger \\
(1144-2022)\end{array}$ & $\begin{array}{l}2272 \\
(1894-2727)\end{array}$ & $\begin{array}{l}2459 \\
(1884-2872)\end{array}$ \\
\hline Gly & $\begin{array}{l}1284^{*} \dagger \\
(876-1586)\end{array}$ & $\begin{array}{l}3053 \\
(2421-3627)\end{array}$ & $\begin{array}{l}2940^{*} \\
(2099-4306)\end{array}$ & $\begin{array}{l}3098 \\
(1745-4533)\end{array}$ & $\begin{array}{l}3397 \\
(1798-4416)\end{array}$ & $\begin{array}{l}5125 \\
(3140-7447)\end{array}$ & $\begin{array}{l}4475 \\
(2066-6521)\end{array}$ \\
\hline Thr & $\begin{array}{l}190^{* \dagger} \\
(162-247)\end{array}$ & $\begin{array}{l}376 \\
(316-185)\end{array}$ & $\begin{array}{l}133^{* \dagger} \dagger \\
(97-192)\end{array}$ & $\begin{array}{l}309 \\
(239-368)\end{array}$ & $\begin{array}{l}2 / 3^{*} \uparrow \\
(138-307)\end{array}$ & $\begin{array}{l}343 \\
(280-446)\end{array}$ & $\begin{array}{l}347 \\
(304-408)\end{array}$ \\
\hline His & $\begin{array}{l}83^{*} \dagger \\
(49-108)\end{array}$ & $\begin{array}{l}125 \\
(107-149)\end{array}$ & $\begin{array}{l}106 \\
(71-182)\end{array}$ & $\begin{array}{l}182 \\
(62-414)\end{array}$ & $\begin{array}{l}92 \\
(73-112)\end{array}$ & $\begin{array}{l}112 \\
(75-135)\end{array}$ & $\begin{array}{l}125 \\
(71-200)\end{array}$ \\
\hline $\mathrm{Cit}$ & $\begin{array}{l}33^{*} \dagger \\
(24-41)\end{array}$ & $\begin{array}{l}110 \\
(56-160)\end{array}$ & $\begin{array}{l}89 * \\
(7 \mid-144)\end{array}$ & $\begin{array}{l}132 \\
(74-244)\end{array}$ & $\begin{array}{l}122 \\
(96-173)\end{array}$ & $\begin{array}{l}154 \\
(|50-19|)\end{array}$ & $\begin{array}{l}142 \\
(82-216)\end{array}$ \\
\hline Ala & $\begin{array}{l}740+ \\
(60 \mid-928)\end{array}$ & $\begin{array}{l}1207 \\
(918-1627)\end{array}$ & $\begin{array}{l}893 \\
(780-1092)\end{array}$ & $\begin{array}{l}1029 \\
(555-1464)\end{array}$ & $\begin{array}{l}662 \dagger \\
(241-\mid 021)\end{array}$ & $\begin{array}{l}1020 \\
(917-1292)\end{array}$ & $\begin{array}{l}834 \\
(632-978)\end{array}$ \\
\hline Tau & $\begin{array}{l}7431 \dagger \\
(3998-11003)\end{array}$ & $\begin{array}{l}10348 \\
(7628-14146)\end{array}$ & $\begin{array}{l}9155 \\
(8035-11708)\end{array}$ & $\begin{array}{l}10216 \\
(5169-12772)\end{array}$ & $\begin{array}{l}8938 \\
(7632-9982)\end{array}$ & $\begin{array}{l}9866 \\
(6647-13000)\end{array}$ & $\begin{array}{l}9443 \\
(6634-12024)\end{array}$ \\
\hline Arg & $\begin{array}{l}76^{*} \dagger \\
(45-100)\end{array}$ & $\begin{array}{l}229 \\
(\mid 55-281)\end{array}$ & $\begin{array}{l}73^{*}+ \\
(46-110)\end{array}$ & $\begin{array}{l}249 \\
(109-496)\end{array}$ & $\begin{array}{l}87^{*} \dagger \\
(64-118)\end{array}$ & $\begin{array}{l}192 \\
(143-235)\end{array}$ & $\begin{array}{l}185 \\
(133-235)\end{array}$ \\
\hline Met & $\begin{array}{l}58^{*} \\
(37-78)\end{array}$ & $\begin{array}{l}49 \\
(42-58)\end{array}$ & $\begin{array}{l}29 \\
(19-42)\end{array}$ & $\begin{array}{l}37 \\
(26-44)\end{array}$ & $\begin{array}{l}22^{*} \\
(16-29)\end{array}$ & $\begin{array}{l}29 \\
(17-38)\end{array}$ & $\begin{array}{l}32 \\
(22-41)\end{array}$ \\
\hline $\operatorname{Trp}$ & $\begin{array}{l}48 \\
(18-82)\end{array}$ & $\begin{array}{l}35 \\
(15-66)\end{array}$ & $\begin{array}{l}51 \\
(14-122)\end{array}$ & $\begin{array}{l}43 \\
(15-117)\end{array}$ & $\begin{array}{l}77 \\
(17-|9|)\end{array}$ & $\begin{array}{l}73 \\
(12-14 \mid)\end{array}$ & $\begin{array}{l}46 \\
(7-85)\end{array}$ \\
\hline Lys & $\begin{array}{l}155 * \dagger \\
(126-194)\end{array}$ & $\begin{array}{l}542 \\
(432-663)\end{array}$ & $\begin{array}{l}259 * \uparrow \\
(173-370)\end{array}$ & $\begin{array}{l}450 \\
(218-807)\end{array}$ & $\begin{array}{l}412 \\
(228-631)\end{array}$ & $\begin{array}{l}416 \\
(281-580)\end{array}$ & $\begin{array}{l}442 \\
(400-476)\end{array}$ \\
\hline Val & $\begin{array}{l}129 \\
(98-176)\end{array}$ & $\begin{array}{l}145 \\
(108-200)\end{array}$ & $\begin{array}{l}72^{*} \\
(51-99)\end{array}$ & $\begin{array}{l}86 \\
(60-104)\end{array}$ & $\begin{array}{l}78^{*} \dagger \\
(48-110)\end{array}$ & $\begin{array}{l}125 \\
(116-143)\end{array}$ & $\begin{array}{l}114 \\
(104-125)\end{array}$ \\
\hline $\mathrm{He}$ & $\begin{array}{l}68 * \\
(55-98)\end{array}$ & $\begin{array}{l}68 \\
(42-94)\end{array}$ & $\begin{array}{l}33^{*} \\
(20-42)\end{array}$ & $\begin{array}{l}30 \\
(20-37)\end{array}$ & $\begin{array}{l}29 * \\
(14-46)\end{array}$ & $\begin{array}{l}43 \\
(35-52)\end{array}$ & $\begin{array}{l}42 \\
(31-48)\end{array}$ \\
\hline Leu & $\begin{array}{l}235^{*} \\
(160-306)\end{array}$ & $\begin{array}{l}247 \\
(143-346)\end{array}$ & $\begin{array}{l}135^{*} \\
(87-192)\end{array}$ & $\begin{array}{l}160 \\
(65-232)\end{array}$ & $\begin{array}{l}129 \\
(83-197)\end{array}$ & $\begin{array}{l}186 \\
(143-266)\end{array}$ & $\begin{array}{l}180 \\
(138-200)\end{array}$ \\
\hline BCAA & $\begin{array}{l}432^{*} \\
(308-579)\end{array}$ & $\begin{array}{l}460 \\
(286-634)\end{array}$ & $\begin{array}{l}240^{*} \\
(158-333)\end{array}$ & $\begin{array}{l}276 \\
(145-360)\end{array}$ & $\begin{array}{l}236 *+ \\
(145-342)\end{array}$ & $\begin{array}{l}355 \\
(303-456)\end{array}$ & $\begin{array}{l}337 \\
(297-362)\end{array}$ \\
\hline Sum & $\begin{array}{l}13448 * \dagger \\
(8399-17312)\end{array}$ & $\begin{array}{l}20469 \\
(17733-23954)\end{array}$ & $\begin{array}{l}17345^{*} \\
(15382-19292)\end{array}$ & $\begin{array}{l}20865 \\
(|2906-2857|)\end{array}$ & $\begin{array}{l}17917^{*} \dagger \\
(16425-2|2| 1)\end{array}$ & $\begin{array}{l}21868 \\
(20979-23330)\end{array}$ & $\begin{array}{l}22148 \\
(17871-25441)\end{array}$ \\
\hline
\end{tabular}

Table 7. Gastrocnemius and plasma concentrations of glutamate, glutamine and arginine measured 12 days after treatment. Values are given as mean (range) for six to eight rats. Abbreviations: CON, ad libitum fed control rats; ZYM, zymosan-injected rats; PF, pair-fed rats, *Significantly different from control rats; fsignificantly different from pair-fed rats.

\begin{tabular}{|c|c|c|c|c|c|c|}
\hline & \multicolumn{3}{|c|}{ Muscle } & \multicolumn{3}{|c|}{ Plasma } \\
\hline & $\begin{array}{l}\text { Glu }(\mu \mathrm{mol} / \mathrm{g} \\
\text { wet } w t)\end{array}$ & $\begin{array}{l}\text { Gln }(\mu \mathrm{mol} / \mathrm{g} \\
\left.\text { wet } w t_{.}\right)\end{array}$ & $\begin{array}{l}\text { Arg (nmol/g } \\
\text { wet wh.) }\end{array}$ & $\begin{array}{l}\text { Glu } \\
(\mu \mathrm{mo} \mid \mu)\end{array}$ & $\begin{array}{l}\text { Gln } \\
(\mu \mathrm{mol} / 1)\end{array}$ & $\begin{array}{l}\operatorname{Arg} \\
(\mu \mathrm{mol} / l)\end{array}$ \\
\hline CON & $2.5(2.2-3.0)$ & $3.4(2,7-4.4)$ & $259(|6|-360)$ & $174(130-219)$ & $727(588-8 \mid 0)$ & $201(188-220)$ \\
\hline ZYM & $2.1(1.9-2.9)$ & $3.3(2.9-4.0)$ & $333(212-402)$ & $89(69-97)^{*}$ & $545(493-594)^{*+}$ & $125(104-148)^{*} \dagger$ \\
\hline $\mathrm{PF}$ & $2.3(2.0-2.6)$ & $3.4(3.3-4.2)$ & $368(247-568)$ & $127(108-165)$ & $692(561-9 \mid 5)$ & $190(160-231)$ \\
\hline
\end{tabular}

concentrations of glutamine and protein synthesis rates in muscle both in vitro [30] and in vivo [31]. Rennie et al. [32] hypothesized that a fall in muscle glutamine concentration is causally related to muscle wasting in patients. No such correlation $(P=0.4904)$ was found in the zymosan-treated rats
(Fig. 3) due to the normalization of protein synthesis rates on day 6 in the zymosan-treated rats in combination with reduced muscle concentrations of glutamine. Also, Wusteman et al. [18] came to the conclusion that this relation is not a universal one.

Concentrations of arginine were decreased in 


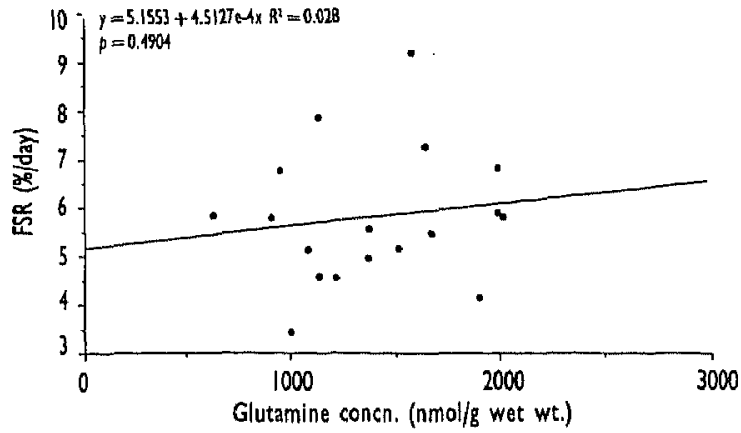

Fig. 3. Relationship between muscle concentrations of glutamine and muscle FSR in the zymosan-treated rats measured on days 2, 4 and 6. The Spearman rank correlation was used for statistical analysis.

muscle 2 and 6 days after zymosan treatment. Plasma concentrations, however, were reduced on days 4, 6 and 12. Arginine has also been suggested as an indispensable dietary amino acid in clinical conditions such as starvation, injury or stress due to its metabolic functions during growth, wound healing and tumour cell killing [33]. The decreased concentrations of arginine in the zymosan-treated rats both in plasma and muscle, therefore, may lead to an impaired recovery.

We conclude that injection of a single dose of zymosan in rats leads to metabolic derangements both during the acute phase of critical illness and during the prolonged recovery phase. The model seems suited for investigating the biochemical mechanisms behind these metabolic derangements and for studying therapeutic and nutritional interventions during recovery from critical illness.

\section{ACKNOWLEDGMENTS}

We thank Dr N. E. P. Deutz and Mr H. M. H. Van Eijk for performing the amino acid analyses. This research was supported by a grant from DMV International, a division of Campina Melkunie bv, Veghel, The Netherlands.

\section{REFERENCES}

1. Ardaw| MSM. Majzoub MF. Glutamine metabolism in skeletal muscle of septic rats. Metab Clin Exp 1991; 40: 155-64.

2. Wichterman KA, Baue AE, Chaudry IH. Sepsis and septic shock-a review of laboratory models and a proposal. J Surg Res 1980; 29: 189-201.

3. Ardawi MSM. Skeletal muscle glutamine production in thermally injured rats. Clin Sci 1988; 74: 165-72

4. Fong $Y$, Minei JP, Marano $A_{1}$ et al. Skeletal muscle amino acid and myofibrillar protein $m R N A$ response to thermal injury and injection. Am J Physiol 1991; 261: R536-42.

5. Jepson MM, Pell JM, Bates PC, Millward DJ. The effect of endotoxaemia on protein metabolism in skeletal muscle and liver of fed and fasted rats. Biochem ] 1986; 235: 329-36.

6. Goris RJA, Boekholtz WKF, Van Bebber IPT, Nuytinck JKS, Schilling PHM.
Multiple organ failure and sepsis without bacteria. An experimental model Arch Surg 1986; 121: 897-901.

7. Van Bebber IPT, Boekholz WKF, Goris RJA, et al. Neutrophil function and lipid peroxidation in a rat model of multiple organ failure. I Surg Res 1989; 47: $47 \mid-5$.

8. Schrimer WJ, Schrimer JM, Naff GB, Fry DE. Systemic complement activation produces hemodynamic changes characteristic of sepsis. Arch Surg 1988: 123: $3|6-2|$.

9. Steinberg S, Flynn W, Kelly K, et al. Development of a bacteria-independent model of the multiple organ failure syndrome. Arch Surg 1989; 124: 1390-5.

10. Garlick P), McNurlan MA. Preedy VR. A rapid and convenient technique for measuring the rate of protein synthesis in tissue by injection of ['H]phenylalanine. Blochem J 1980; 192: 719-23.

II. Lowry $\mathrm{OH}$, Rosebrough NI, Farr AL, Randall RI. Protein measurement with the Folin phenol reagent. J Biol Chem 1951; 193: 265-75.

12. Van Eijk HMH, Vander Heijden MAH, Van Berlo CH, Soeters PB. Fully automated liquid-chromatographic determination of amino acids. Clin Chem 1988; 34: 2510-13.

13. Lund P. L-Glutamine and L-glutamate. In: Bergmeyer HU, ed. Methods of enzymatic analysis. Weinheim: VCH Publishers, 1990; 357-63.

14. Gäde G. Arginine and arginine phosphate. In: Bergmeyer HU, ed. Methods of enzymatic analysis. Weinheim: VCH Publishers, 1990; 425-31.

15. Fink MP, Heard SO. Current research review. Laboratory models of sepsis and septic shock. I Surg Res 1990; 49: 186-96.

16. Jacobson HR. Fluid and electrolyce problems in surgery, trauma, and burns, In: Kokko JP, Tannen RL, eds. Fluid and electrolytes. Philadelphia: W.B. Saunders Company, 1986: 791-816.

17. Rennie MI, Harrison R, Effect of injury, disease and malnutrition on protein metabolism in man. Unanswered questions. Lancet 1984; i: 323-5.

18. Wusteman $M$, Wight DGD, Elia M. Protein metabolism aiter injury with turpentine: a rat model for clinical trauma, Am | Physiol 1990; 259: E763-9.

19. Emery PW, Lovell L, Rennie MJ. Protein synthesis measured in vivo in muscle and liver of cachectic tumor-bearing rats. Cancer Res 1984; 44; 2779-84.

20. Fürst P. Intracellular muscle free amino acids-their measurement and function. Proc Nutr Soc 1983; 42: 451-62.

21. Freund $H_{1}$ Atamian $S$, Holroyde J, Fischer JE. Plasma amino acids as predictors of the severity and outcome of sepsis. Ann Surg 1979; 190:57I-76.

22. Stinnetr JD, Alexander JW. Watanabe $C$, et al. Plasma and skeletal muscle amino acids following severe burn injury in patients and experimental animals. Ann Surg 1982; 195: 75-89.

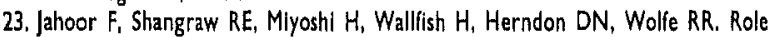
of insulin and glucose oxidation in mediating the protein catabolism of burns and sepsis. Am ] Physiol 1989; 257: E323-31.

24. Tischler ME, Fagan JM. Response to trauma of protein, amino acid, and carbohydrate metabolism in injured and uninjured rat skeletal muscles. Metab Clin Exp 1983; 32; 853-67.

25. Fürst $P$, Bergström J, Kinney JM, Vinnars E. Nutrition in postoperative catabolism. In: Richards JR, Kinney JM, eds. Nutritional aspects of care in the critically ill. 3. New York: Churchill Livingstone, 1977: 389-410.

26. Askanazi I, Carpentier YA, Michelsen CB, et al. Muscle and plasma amino acids following injury. Ann Surg 1980; 192: 78-85.

27. Petersson $B$, Vinnars $E$, Waller S-O, Wernerman I. Long-term changes in muscle free amino acid levels after elective abdominal surgery. Br J Surg 1992; 79: $212-16$

28. Krebs $\mathrm{H}$. Glutamine metabolism in the animal body. In: Mora J, Palacios $\mathrm{R}$, eds. Glutamine: metabolism, enzymology and regulation. New York: 1980: 319-29.

29. Lacey JM, Wilmore DW. Is glutamine a conditionally essential amino acid? Nutr Rev 1990; 48: 297-309.

30. Maclennan PA, Brown RA, Rennie MJ. A positive relationship between protein synthetic rate and intercellular glutamine concentration in perfused rat skeletal muscle. FEBS Lett 1987; 215; 187-9|.

31. Jepson MM, Bates PC, Broadbent P, Pell JM, Millward DJ. Relationship between glutamine concentration and protein synthesis in rat skeletal muscle. Am J Physiol 1988; 255: El66-72.

32. Rennie MI, Babil $P$, Taylor PM, et al. Characteristics of a glutamine carrier in skeletal muscle have important consequences for nitrogen loss in injury, infection and chronic disease. Lancet 1986; Ili 1008-12.

33. Barbul A. Arginine: biochemistry, physiology, and therapeutic implications. J Parenteral Enteral Nutr 1986; 10: 227-38. 